[Agr. Biol. Chem., Vol. 28, No. 9, p. 605 609, 1964]

\title{
Studies on the Isomerization of Sugars by Bacteria
}

\section{Part VIII. Purification and Some Properties of Mannose Isomerase from Xanthomonas rubrilineans S-48}

\author{
By Yoshiyuki TAkASaki, Shuntaro TAKano* and \\ Osamu Tanabe \\ Fermentation Research Institute, Ministry of International Trade and Industry, \\ Inage, Chiba City, Japan \\ Received December 24, 1963
}

\begin{abstract}
Crude mannose isomerase preparation from Xanthomonas rubrilineans S-48 which converts D-mannose to $\mathrm{D}$-fructose was further purified by ammonium sulfate fractionation and DEAE-cellulose column chromatography. The specific activity of the purified enzyme solution was about 35 -fold of original crude preparation. By using this purified enzyme solution, several enzymatic properties were investigated.

(1) The Michaelis constant was $1.2 \times 10^{-2} \mathrm{M}$. (2) The enzyme was sensitive against temperature, but $\mathrm{Ca}^{++}$protected the enzyme to some extent from the effect of temperature. (3) The enzyme was stable in the $\mathrm{pH}$ range from 6 to 9. (4) The enzyme was not inhibited by glucose, xylose, mannitol, sorbitol, mannonic acid, mannuronic acid and so on, but strongly inhibited by D-arabinose and $\mathrm{L}$-fucose, and $\mathrm{Ki}$ values of these inhibitors were $1.1 \times 10^{-2} \mathrm{M}$ and $7.1 \times 10^{-4} \mathrm{M}$ respectively.
\end{abstract}

\section{INTRODUCTION}

In the previous paper, ${ }^{1,2)}$ authors reported that a newly isolated bacterium having mannose isomerase was identified as Xanthomonas rubrilineans; the enzyme was corstitutive and widely distributed in bacteria which belong to Xanthomonas.

The present report deals with purification and some properties of mannose isomerase from Xanthomonas rubrilineans S-48.

\section{EXPERIMENTAL}

Organism.

The organism used in this paper was Xanthomonas rubrilineans S- 48 isolated by the author.

Assay of mannose isomerase activity.

The assay of mannose isomerase was carried out as follows: The reaction mixture was prepared by adding $1 \mathrm{ml}$ of $0.1 \mathrm{M}$ phosphate buffer solution $(\mathrm{pH} 8)$ and 0.2

\footnotetext{
1) X. Takasaki, O. Tanabe, J. Agr. Chem. Soc. Japan, 37, 524 (1963).

2) Y. Takasaki, O. Tanabe, This Journal, 28, 601 (1964).

* Present address; Seisei K.K., 4, Shimura-chio, Itabashi-ku, Tokyo.
}

$\mathrm{ml}$ of $0.1 \mathrm{M}$ mannose to the enzyme solution to make the total volume $2 \mathrm{ml}$. The reaction mixture was incubated for thirty to sixty minutes at $35^{\circ} \mathrm{C}$. The reaction was stopped by the addition of $2 \mathrm{ml}$ of $0.5 \mathrm{M}$ perchloric acid. Fructose formed was determined by the cysteinecarbazole method.

The amount of enzyme which will produce $1 \mu \mathrm{M}$ of fructose from mannose per hour at $35^{\circ} \mathrm{C}$ under the above assy condition is defined as a unit of the enzyme.

Determination of protein.

Protein was determined by the Lowry's method.

\section{Purification of enzyme.}

$X$. rubrilineans $\mathrm{S}-48$ was grown in the synthetic medium containing $1 \%$ glucose as a sole carbon source as previously described. The cells were centrifuged, washed twice with $0.02 \mathrm{M}$ phosphate buffer solution ( $\mathrm{pH} \mathrm{7)}$, suspended in the same buffer solution and then the cell suspension was sonicated at a frequency of $10 \mathrm{KC}$ for fifteen to twenty minutes. After centrifugation at $10,000 \mathrm{rpm}$ for ten minutes, the supernatant $(80 \mathrm{ml})$ was brought to $40 \%$ saturation by the addition of $19.2 \mathrm{~g}$ of solid ammonium 
sulfate and was adjusted to $\mathrm{pH} 7$ by the addition of ammonia. After being stirred for ten minutes under low temperature, the mixture was centrifuged and the supernatant brought to $60 \%$ saturation by adding $10.6 \mathrm{~g}$ of solid ammonium sulfate. After ten minutes, the suspention was centrifuged and the precipitate was dissolved in $20 \mathrm{ml}$ of water and treated with $1.8 \mathrm{ml}$ of $2 \%$ protamin. The $40 \sim 60 \%$ fraction by the addition of solid ammonium sulfate was collected in the same way as above. The precipitate was dissolved in $10 \mathrm{ml}$ of water and the centrifuged supernatant was then dialyzed overnight against 11 of $0.02 \mathrm{M}$ phosphate buffer solution ( $\mathrm{pH} 7$ ) containing $5 \times 10^{-3} \mathrm{M}$ cysteine. The precipitate in the dialyzed bag was centrifuged and the supernatant poured onto a DEAEcellulose column $(1.3 \times 18 \mathrm{~cm})$ which was pretreated with $0.02 \mathrm{M}$ phosphate buffer solution $(\mathrm{pH} 7)$. The enzyme absorbed by the column was eluted with $0.02 \mathrm{M}, 0.05 \mathrm{M}$, $0.1 \mathrm{M}$ and $0.2 \mathrm{M}$ phosphate buffer solution ( $\mathrm{pH} 7$ ). Flow rate was approximately $5 \mathrm{ml}$ per hour and the elute was collected every $5 \mathrm{ml}$.

The results of the purification processes are shown in Table I. Fig. I shows the result of the enzyme elution from this column.

\section{RESULTS AND DISCUSSION}

\section{Influence of Mannose Concentration}

The results of an experiment with different concentration of mannose is shown in Fig. 2. Fig. 2 also shows the reciprocal of velocity against the reciprocal of substrate concentration, and the calculation of apparent Michaelis constant gave a value of $1.2 \times 10^{-2} \mathrm{M}$. It is observed that the enzyme was slighty inhibited by high substrate concentration.

\section{Stability Against Heat}

One tenth $\mathrm{ml}$ of enzyme solution and $1 \mathrm{ml}$ of buffer solution $(0.1 \mathrm{~m}$ phosphate buffer and $0.1 \mathrm{M}$ phosphate buffer containing $1 \times 10^{-2} \mathrm{M} \mathrm{CaCl}_{2}$ )

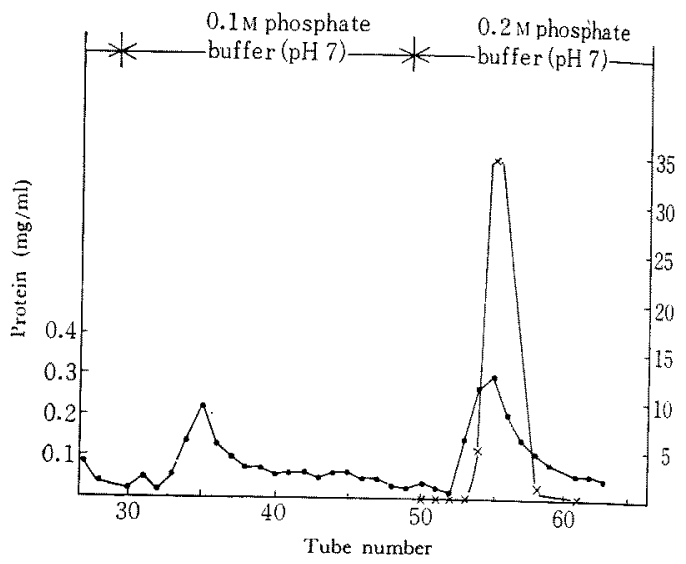

FIG. 1. Separation of Mannose Isomerase by DEAECellulose Column Chromatography.

Column; $1.3 \times 18 \mathrm{~cm}$, Flow rate; $5 \mathrm{ml} / \mathrm{hr}$, Fraction; $5 \mathrm{ml}$ - Protein, $x \longrightarrow x$ Activity

were mixed and treated at various temperature After five minutes treating, the reaction $\mathrm{mix}$ tures were immediately cooled and added with $0.2 \mathrm{ml}$ of $0.1 \mathrm{M}$ mannose to make the final volume $2 \mathrm{ml}$ and the residual enzyme activities were measured. The results are shown in Fig. 3 The enzyme is unstable above $40^{\circ} \mathrm{C}$, but is stabilized in the presence of $\mathrm{Ca}^{++}$.

\section{pH stability}

To $1 \mathrm{ml}$ of each buffer solution (Macllvane buffer and Sörensee buffer), $0.2 \mathrm{ml}$ of enzyme solution was added and the mixture was kept at room temperature $\left(27^{\circ} \mathrm{C}\right)$ for five hours. After adjustment of $\mathrm{pH}$ to $8,0.2 \mathrm{ml}$ of $0.1 \mathrm{M}$ mannose was added to make the final volume $2 \mathrm{ml}$ and the residual enzyme activities were measured. The result shown in Fig. 4 indicates that the mannose isomerase is stable under the $\mathrm{pH}$ range

Table I. Summary of the Purification Procedure of Mannose Isomerase

$\begin{array}{lcccrc} & \begin{array}{c}\text { Total-volume } \\ (\mathrm{ml})\end{array} & \begin{array}{c}\text { Protein } \\ (\mathrm{mg})\end{array} & \begin{array}{c}\text { Total activity } \\ \text { (unit) }\end{array} & \begin{array}{c}\text { Specific } \\ \text { activity }\end{array} & \begin{array}{c}\text { Yield } \\ (\%)\end{array} \\ \text { Wet cells }(6.2 \mathrm{~g}) & 80 & 620 & 2,356 & 3.8 & 100 \\ \text { Cell extracts } & 20 & 115 & 1,111 & 9.7 & 47.6 \\ \text { Amm. sulfate }(40 \sim 60 \%) & 40 & 69 & 996 & 14.4 & 42.2 \\ \text { Protamine treatment } & 10 & 56 & 1,040 & 18.6 & 44.1 \\ \text { Amm. sulfate }(40 \sim 60 \%) & & 43 & 917 & 21.1 & 38.9 \\ \text { Dialysis } & & 4.4 & 576 & 130.8 & 24.5 \\ \text { DEAE-cellulose } & & & & & \end{array}$




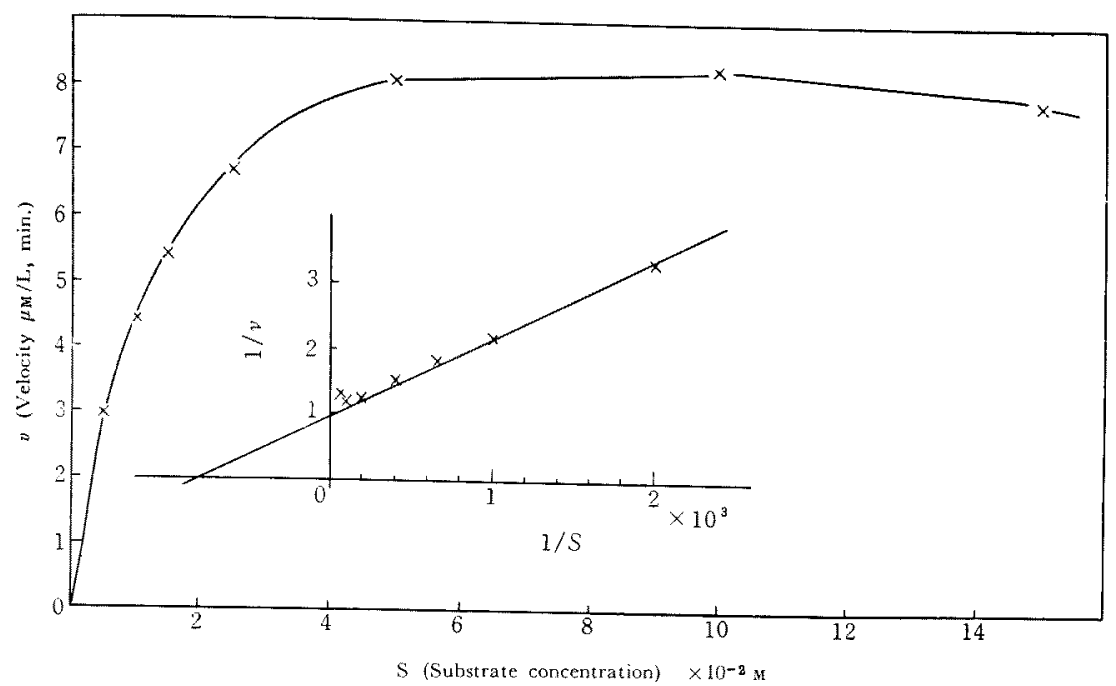

Fig. 2. Influence of Mannose Concentration.

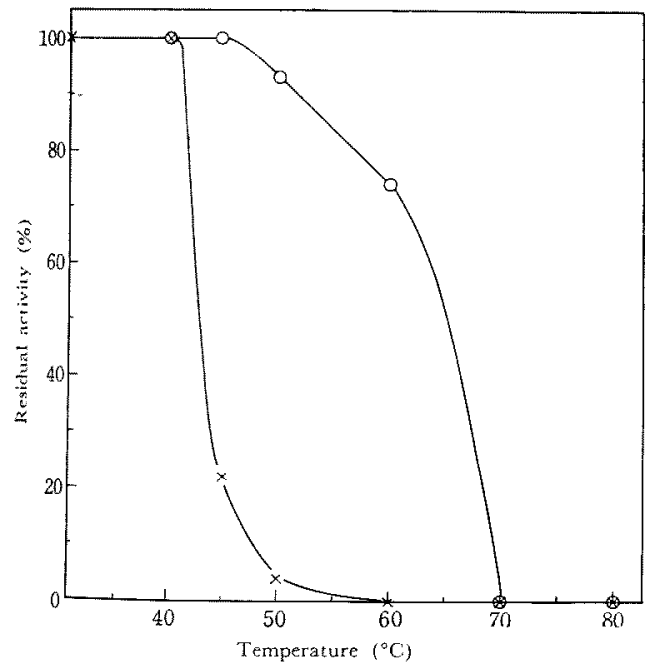

FIG. 3. Stability against Heat

$x \longrightarrow$ xone, $\quad-0 \mathrm{CaCl}_{2}\left(1 \times 10^{-2} \mathrm{M}\right)$

from 6 to 9, but is unstable below pH 6 or above $\mathrm{pH} 9$.

\section{Effect of other Substance}

$T_{0}$ the reaction mixture containing $0.02 \mathrm{M}$ of mannose, $0.01 \mathrm{M}$ of one of other substance such as D-glucose, D-xylose, D-mannitol, D-mannonic-

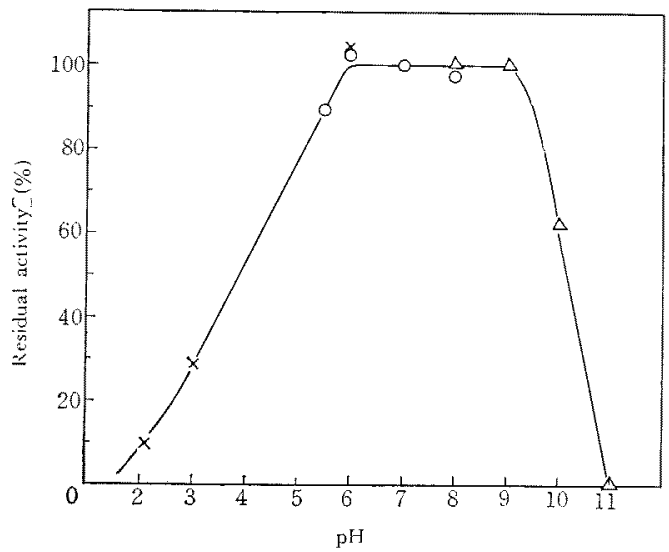

Frg. 4. pH Stability

Macllvaine buffer (citrate- $\mathrm{Na}_{2} \mathrm{HPO}$ Sorensen bufer ( $\mathrm{KH}_{2} \mathrm{PO},-\mathrm{Na}_{2} \mathrm{HPO}_{4}$ Sörensen buffer (glycol-NaOH)

acid and so on was added in order to test their effect. Of them, D-arabinose and $\mathrm{L}$-fucose showed strong inhibitory effect, however, D-glucose, Dgalactose D-xylose, D-mannitol, D-sorbitol, D-mannonic acid and D-mannuronic acid etc. did not inhibit the enzyme. The results are shown in Table II.

In order to determine whether these inhibitions by $\mathrm{D}$-arabinose and $\mathrm{L}$-fucose are competitive or 
Table II. Effect of Other Substance

\begin{tabular}{lc}
\multicolumn{1}{c}{ Substance } & Relative activity \\
None & 100 \\
D-Glucose & 98.2 \\
D-Galactose & 100 \\
D-Sorbose & 100 \\
D-Mannitol & 100 \\
D-Sorbitol & 100 \\
D-Gluconic acid & 98.2 \\
D-Mannonic acid & 100 \\
D-Glucuronic acid & 100 \\
D-Mannuronic acid & 100 \\
D-Xylose & 100 \\
D-Ribose & 100 \\
L-Rhamnose & 98.8 \\
D-Arabinose & 51.5 \\
L-Arabinose & 100 \\
L-Fucose & 23.5 \\
D-Glucosamine & 94.5 \\
D-Glucosone & 94.2 \\
Reaction mixture was prepared by adding $1 \mathrm{ml}$ of $0.1 \mathrm{~m}$ phosphate \\
buffer solution (pH 8), $0.4 \mathrm{ml}$ of $0.1 \mathrm{M}$ mannose and $0.2 \mathrm{ml}$ of $0.1 \mathrm{M}$ \\
other substance to the $0.2 \mathrm{ml}$ af enzyme solution to make the total \\
volume 2 mi and incubated for 30 minutes at $35^{\circ} \mathrm{C}$.
\end{tabular}

not, the reciprocals of velocities in the presence and absence of inhibitors $\left(1 \times 10^{-2} \mathrm{M}\right)$ were ploted against the reciprocals of substarate concentrations. The results shown in Fig. 5 suggest that these inhibitions are competitive since the intercept does not change. From the inclination of the lines, the $\mathrm{Ki}$ values were calculated to be $1.1 \times 10^{-2} \mathrm{M}$ for $\mathrm{D}$-arabinose and $7.1 \times 10^{-4} \mathrm{M}$ for L-fucose.

Palleroni and Doudroff ${ }^{3)}$ reported that the structure of sugar, being necessarily be the substrate for mannose isomerase, shoud be the same as that of mannose in the structural configuration of the first five carbon atoms, since D-lyxose and D-rhamnose were also attacked by this iso-

3) N.J. Palleroni, M. Doudroff, J. Biol. Chem., 218, 535 (1956)

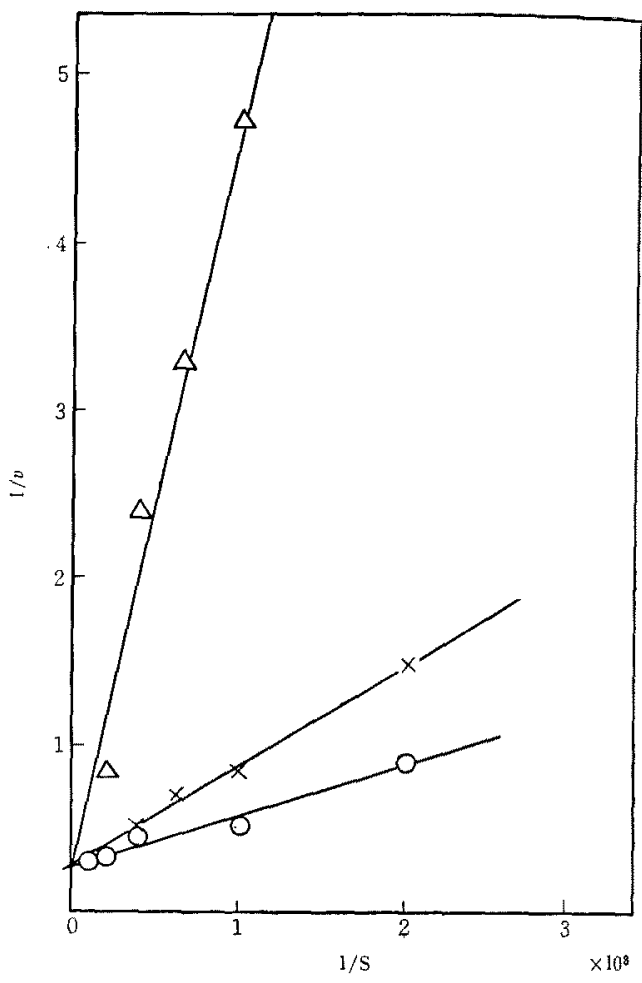

FIG. 5. Competitive Inhibition of Mannose Isomerase by $D$-Arabinose and L-Fucose.

$-\triangle-$ L-Fucose $-X-$ D-Arabinose $-O-$ None

merase (Fig. 6). In our experiment, althougt D-lyxose and D-rhamonose were not tested, it wa. found that D-glucose, D-galactose, L-rhamnose D-xylose, D-arabinose and $\mathrm{L}$-fucose were not at tacked by the mannose isomerase, and furthe found that $\mathrm{D}$-arabinose and $\mathrm{L}$-fucose shower strong inhibitory action for the mannose iso merase. The structures of these two sugars diffe from that of mannose, which can be attackes by the enzyme, from a view-point of the struc tural configuration of the $\mathrm{OH}$ group at th third carbon atom within first five carbon atom (Fig. 6). These facts indicate that $D$-arabinos and $\mathbf{L}$-fucose have the structures which are cap $c^{2}$ ble to bound to mannose isomerase, though the sugars are not attacked by mannose isomerase 


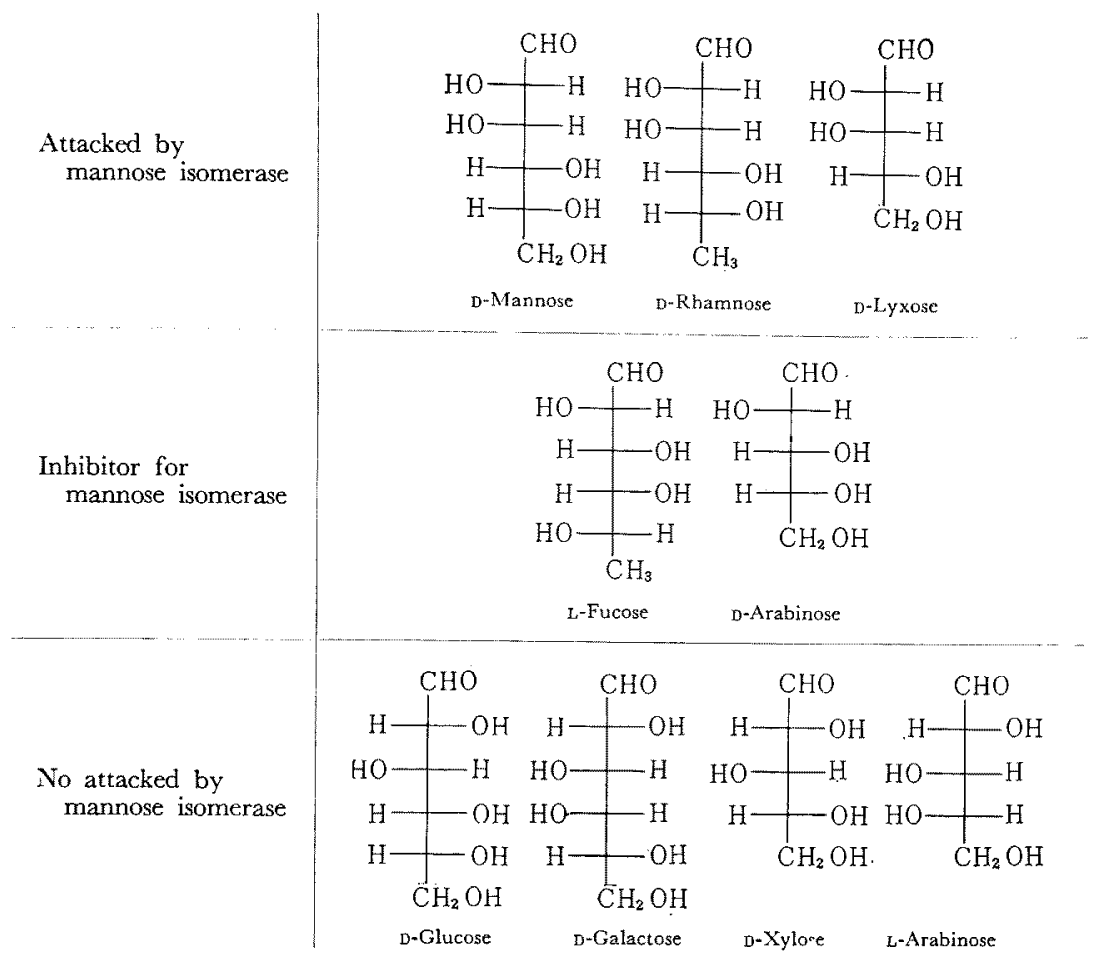

FIG. 6. Structure of Sugar Capable of Combining with Mannose Isomerase

Acknowledgment. The authors wish to thank for many helpful discussions. Dr. A. Sato and Dr. J. Ooyama of our Institute 